\title{
Intracellular Calcium-Binding Proteins in Signal Transduction
}

\author{
Jos A. Cox*
}

Abstract. Cell stimulation generates a $\mathrm{Ca}^{2+}$ signal, which is perceived by intracellular $\mathrm{Ca}^{2+}$-binding proteins. These proteins are made up of different units of a conserved structural motif, called the $2 S$ domain, and composed mainly of four $\beta$-helices and two anti parallel $\beta$-strands. This $2 \mathrm{~S}$ domain can bind $2 \mathrm{Ca}^{2+}$ ions and is roughly cup-shaped in the $\mathrm{Ca}^{2+}$-bound configuration. The interior of the cup is lined with solvent-exposed hydrophobic residues. In $\mathrm{Ca}^{2+}$-binding proteins involved in cellular signal-response coupling, such as calmodulin and troponin $\mathrm{C}$, the hydrophobic cup is essential for interaction with, and activation of the response proteins. The $\mathrm{Ca}^{2+}$-free state is characterized by a reorientation of the $\beta$-helices and shielding of the hydrophobic residues in the cup. In contrast, interaction with the target strongly stabilizes the hydrophobic cups. $\mathrm{Ca}^{2+}$-buffering proteins, such as parvalbumin and sarcoplasmic $\mathrm{Ca}^{2+}$-binding proteins, have intrinsically a stable conformation, since the strongly hydrophobic cups are stabilized by frontal self association of the $2 \mathrm{~S}$ domains.

Many external signals, like hormones, growth factors, sensory stimuli, neurotransmitters, or nerve impulses, are translated into intracellular information via the so-called $\mathrm{Ca}^{2+}$ signal, i.e. a transient increase in the free $\mathrm{Ca}^{2+}$ concentration from the resting $0.1 \mu \mathrm{M}$ to peak values ranging from 0.2 to $2 \mu \mathrm{m}$. The $\mathrm{Ca}^{2+}$ signal is regulated by a number of devices at the level of the plasma membrane and of intracellular vesicles. The $\mathrm{Ca}^{2+}$ signal is useless, unless it can be conveyed to the cellular response systems, which range from muscle contraction, cell division, secretion, metabolic changes, perception to memory storage. Selected proteins are obligatory intermediates between the $\mathrm{Ca}^{2+}$ signal and the cell response. We call these proteins $\mathrm{Ca}^{2+}$ vectors. They bind $\mathrm{Ca}^{2+}$ with affinities compatible with the $\mathrm{Ca}^{2+}$ transients and undergo $\mathrm{Ca}^{2+}$ dependent conformational changes. Their $\mathrm{Ca}^{2+}$-filled conformation forms a complex with the response enzyme or protein and turns it 'on'. The identification of more and more $\mathrm{Ca}^{2+}$-binding proteins [1], revealed that a discrimination must be made between activator proteins and $\mathrm{Ca}^{2+}$-binding proteins that buffer the

\footnotetext{
*Correpondence: Dr. J.A.Cox

Department of Biochemistry

Faculty of Science

University of Geneva

30, quai Ernest-Ansermet

$\mathrm{CH}-1211$ Geneva 4
}

$\mathrm{Ca}^{2+}$ and $\mathrm{Mg}^{2+}$ concentrations inside the cell. The former act at low concentrations and can be considered as catalysts. The latter occur at high concentrations in cells, interfere with the $\mathrm{Ca}^{2+}$ signal and buffer intracellular $\mathrm{Ca}^{2+}$ and $\mathrm{Mg}^{2+}$, but do not get involved in protein-protein contacts. Activator proteins can also buffer intracellular $\mathrm{Ca}^{2+}$, provided they are present in the cells in considerable amounts (e.g. calmodulin); buffering proteins will never act as activators.

For two decades, we studied the structure-function relationship of many different $\mathrm{Ca}^{2+}$-binding proteins. In this overview, we briefly consider the structural similarities and differences between $\mathrm{Ca}^{2+}$ buffers and activators. Emphasis is placed on two invertebrate $\mathrm{Ca}^{2+}$-binding proteins which were identified, isolated and characterized for the first time by our group in Geneva. One is a buffer, namely the sarcoplasmic $\mathrm{Ca}^{2+}$-binding protein present in many invertebrates. The second is an activator, namely the $\mathrm{Ca}^{2+}$ vector protein of the lancelet.

\section{EF-Hand Containing $\mathrm{Ca}^{2+}$-Binding Proteins: Diversity and Structure}

With the exception of the annexins, a family of membrane-associated $\mathrm{Ca}^{2+}$-binding proteins, and some isolated proteins such as gelsolin, the vast majority of $\mathrm{Ca}^{2+}$ binding proteins possesses a common structural motif, named the EF-hand [2].
The EF-hand consists of a 12 residue-long loop, flanked by two short $\alpha$-helices ( $F$ ig., right side). The loop provides the oxygens for the coordination of $\mathrm{Ca}^{2+}$. The $\alpha$-helices are characterized by a number of wellconserved hydrophobic positions. Intrinsically, the EF-hand is not stable: in all structurally resolved $\mathrm{Ca}^{2+}$-binding proteins stabilization is obtained by pairing of two EF-hands domains to form a 2-sites domain, named here $2 S$ domain (Fig.). The $2 \mathrm{~S}$ domain is characterized by a short antiparallel $\beta$-pleated sheet and an elaborate solvent-exposed hydrophobic patch. The latter is made up of the conserved residues in the helices C, D, E, and F (Fig.). The shape of the $2 S$ domain is that of a ladle with hydrophobic cup. The $2 \mathrm{Ca}^{2+}$ ions sit at the back of the cup and are partially exposed to the solvent. Upon dissociation of $\mathrm{Ca}^{2+}$ the interhelical angle within the single EF-hands changes, and the hydrophobic interactions inside the cup become stronger so that functionally important hydrophobic residues are not exposed anymore to the solvent [3].

Using the $2 S$ domain, nature has constructed very different proteins with this simple module. Frequently, these proteins possess two $2 \mathrm{~S}$ domains. In activators, such as calmodulin and troponin $\mathrm{C}$, the two halves, each composed of a $2 S$ domain, are separated by a central $\alpha$-helix. This unstable conformation with exposed hydrophobic cups is predominant in the presence of $\mathrm{Ca}^{2+}$ and will be stabilized by interaction with the target protein. Amphiphilic peptides, corresponding to the calmodulin-binding domain of natural targets, confer to calmodulin a compact/globular shape, indicating that the central $\alpha$ helix bends so that the two hydrophobic cups can directly interact with the peptide and that the hydrophobicity is hidden in a central core. In $\mathrm{Ca}^{2+}$-buffers, such as parvalbumin and sarcoplasmic $\mathrm{Ca}^{2+}$-binding proteins, the structures are very compact and the hydrophobic cups of the two $2 S$ domains are glued together.

Another vital difference between vectors and buffers is that the vectors possess so-called $\mathrm{Ca}^{2+}$-specific sites, characterized by fast on- and off-rate kinetics and nearly not influenced by $\mathrm{Mg}^{2+}$; the buffers possess slowly-reacting $\mathrm{Ca}^{2+}+\mathrm{Mg}^{2+}$ mixed sites, which slowly exchange $\mathrm{Mg}^{2+}$ for $\mathrm{Ca}^{2+}$ during the $\mathrm{Ca}^{2+}$ signal [4].

\section{Sarcoplasmic $\mathrm{Ca}^{2+}$-Binding Proteins}

In 1973-1980, in search of parvalbumins in invertebrate muscle, we and others discovered another type of soluble sarcoplasmic $\mathrm{Ca}^{2+}$-binding protein in crustaceans, annelids, mollusks, and proto- 
chordates [5]. Recently, sequence studies revealed that a few other ancient proteins belong to the same subfamily: the bioluminescent proteins aequorin and luciferin-binding protein and Streptomyces erythraeus $\mathrm{Ca}^{2+}$-binding protein. SCP's (sarcoplasmic $\mathrm{Ca}^{2+}$-binding protein) do not interact with hydrophobic matrices such as phenyl-Sepharose or fluphenazine-Sepharose. Similarly, none of the SCP's forms stable complexes with short amphiphilic peptides, which often serve as models to monitor the interactions of calmodulin with its target proteins [7]. Neither do immobilized SCP's retain any protein when charged with muscle extracts of different invertebrates. These data suggest that SCP's are incapable of proteinprotein interaction.

Recently, we elucidated the 3-D structure of Nereis SCP [8], which contains typically $3 \mathrm{Ca}^{2+}-\mathrm{Mg}^{2+}$ sites with strict competition between the sites. The protein is very compact with a polar outside. It is characterized by a very hydrophobic interface between the two $2 S$ domains. Studies with two purified trypsin fragments, each with a complete $2 S$ domain, revealed the strong tendency of the $2 \mathrm{~S}$ domains to hide the hydrophobic cup from the solvent [9]. To that effect they form homodimers (when pure) or heterodimers (when mixed). $\mathrm{Ca}^{2+}$ favors the formation of heterodimers; conversely heterodimer formation enhances the affinity for $\mathrm{Ca}^{2+}$. From these studies the following general picture emerged: the $\mathrm{N}$ - and $\mathrm{C}$-terminal lobes can hinge-bend around a flexible hinge in the middle of the polypeptide. In the $\mathrm{Ca}^{2+}$ form, the lobes are glued together so that a solid hydrophobic core is formed. Upon metal removal, the halves slightly move away from each other, implying access of solvent to aromatic residues in the central core and partial de-structuration.

\section{Amphioxus Calcium Vector Protein}

In 1986 , a new $\mathrm{Ca}^{2+}$-binding protein, called CaVP (calcium vector protein), was described [10] in the muscle of the lancelet (amphioxus), the protochordate which is closest in evolution to the vertebrates. This abundant $18 \mathrm{kDa}$ protein binds $2 \mathrm{Ca}^{2+}$ ions with high affinity, apparently at socalled $\mathrm{Ca}^{2+}$-specific sites in the C-terminal half of the protein. The sequence in the $\mathrm{N}$-terminal half also points to the presence of a $2 \mathrm{~S}$ domain, although this does not bind $\mathrm{Ca}^{2+}$. CaVP is highly asymmetric which suggests that the two $2 \mathrm{~S}$ domains are separated. CaVP interacts in a $\mathrm{Ca}^{2+}$ dependent manner with amphiphilic model peptides, similarly to other well-known intracellular $\mathrm{Ca}^{2+}$ vectors such as calmod-

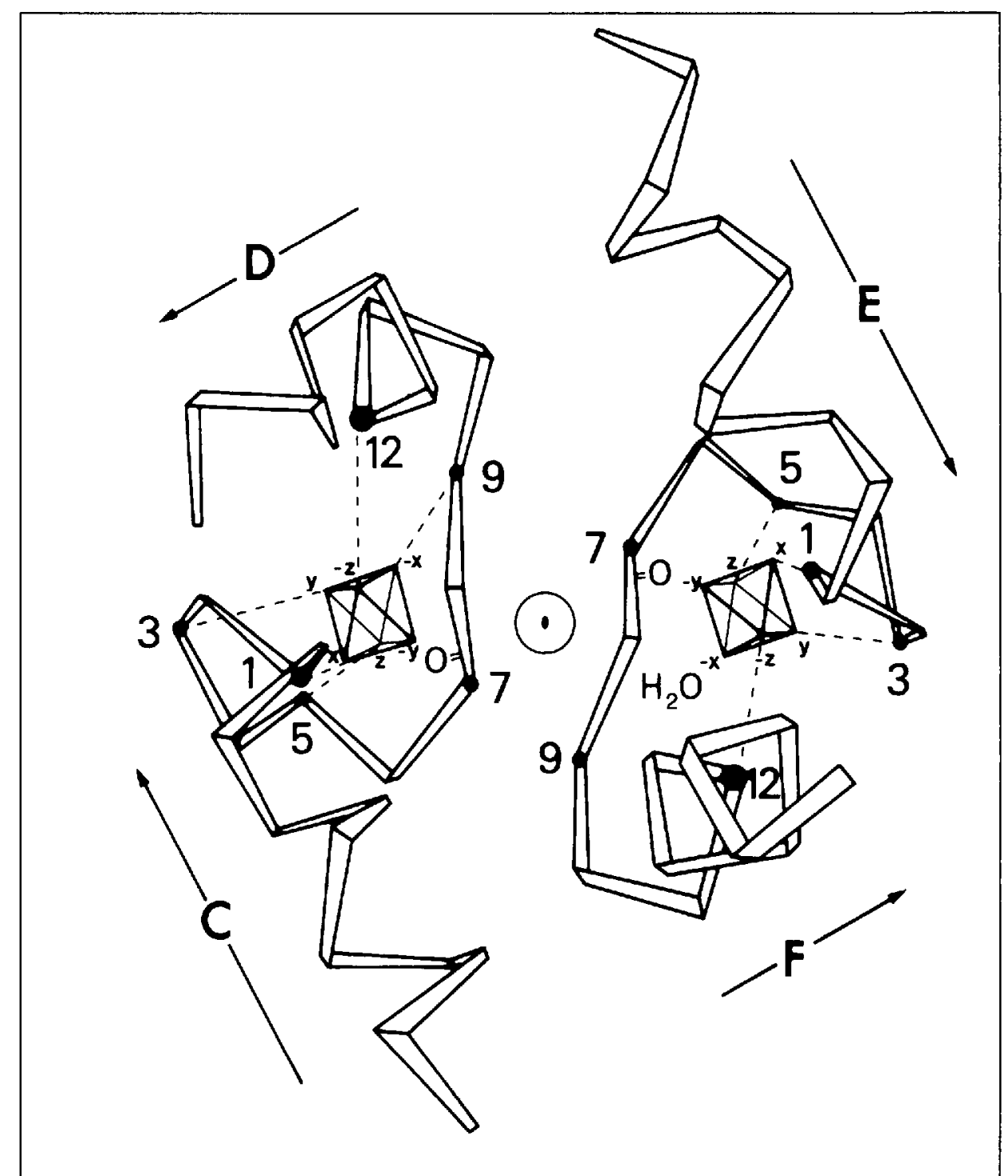

Figure. Peptide backbone of the $2 S$ domain. For simplicity the two EF-hands are not connected at the top. Solid circles represent $\alpha$ carbons of the residues involved in $\mathrm{Ca}^{2+}$ coordination. These residues are numbered according to their position in the $\mathrm{Ca}^{2+}$-binding loop. The $\alpha$ helices are labelled as for parvalbumin according to Kretsinger and Nockolds [14]. The central point represents a twofold symmetry axis. The $\mathrm{Ca}^{2+}$ ions are represented by octahedra; the coordination direction is indicated by dashed lines. This octahedral coordination was the originally proposed structure based on the first detailed X-ray analyses of parvalbumin crystals. Recent refined analyses revealed that $\mathrm{Ca}^{2+}$ is bound in a pentagonal bipyramidal configuration [15]. The conserved Glu residue in the $-\mathrm{Z}(12 \mathrm{th})$ position forms a bidentate ligation with $\mathrm{Ca}^{2+}$.

ulin and troponin $\mathbf{C}$. It can, however, not functionally substitute for the two latter regulators. Its crystal structure has not yet been elucidated, but the rather extensive sequence homology with calmodulin and troponin $\mathrm{C}$ permitted the construction of different three-dimensional models of CaVP based on the crystallographic structure of calmodulin or of troponin C [11]. Both models predict the presence of a long central $\alpha$-helix and of two surface-exposed hydrophobic cups of $c a .700 \AA^{2}$. Taken together, the properties of $\mathrm{CaVP}$ allows its classification as a $\mathrm{Ca}^{2+}$ vector protein, even though its role is not actually known.

In vivo CaVP interacts with an endogenous $26 \mathrm{kDa}$ protein which we called IgCalvin (immunoglobulin-fold-containing CaVP-target protein) [12]. This pro- tein is present in nearly equimolar amounts with CaVP and forms a I:I complex with the latter. The function of the CaVP-IgCalvin complex is not known, but some clues as to the function can be inferred from the amino-acid sequence of IgCalvin. Indeed, besides a CaVP-binding domain, IgCalvin possesses two copies of a 100 residue-1ong sequence motif also present in some proteins interacting with myosin, namely titin, twitchin, projectin, $\mathrm{C}$ protein, and myosin light chain kinase (for compilation, see [13]). The presence of this motif in IgCalvin suggests that the protein recognizes the myosin rod. Very long proteins with multiple (up to 30 ) motifs, such as titin, twitchin, and projectin, seem to act as myosin filament rulers. Shorter proteins, such as $C$ protein ( $S$ motifs), may act as local stabilizers of the 
myosin assemblies. Proteins with one or two copies of the motif may bind to the myosin filaments and exert there their function. Studies are underway to clarify the relationship of the CaVP-IgCalvin complex with myosin filaments and with myosin-stabilizing proteins and how eventual interactions are regulated by the $\mathrm{Ca}^{2+}$ signal.

Studies in our laboratory were supported by the Swiss National Science Foundation.
Received: January 16, 1992

[1] C.W. Heizmann, W. Hunziker, Trends Biochem. Sci. 1991, J6, 98.

[2] R.H. Kretsinger, Cold Spring Harbor Symp. Quant. Biol. 1987, 70, 499.

[3] N.C.J. Strynadka, M.N.G. James, Current Opinion Struct. Biol. 1991, 1, 905.

[4] J.A. Cox, in 'Stimulus-response coupling: The role of intracellular calcium', Eds. J.R. Dedman and V.L. Smith, CRC Press, Boca Raton-Ann Arbor-Boston, 1990, pp. 6772.

[5] W. Wnuk, J.A. Cox, E.A. Stein, in 'Calcium and Cell Function', Ed. W.Y. Cheung, Academic Press, New York, 1981, Vol. 2, p. 243.

[6] J.A. Cox, A. Bairoch, Nature (London) 1988, 331,491 .
[7] J.A. Cox, Biochem. J. 1988, 249, 621.

[8] W.J. Cook, S.E. Ealick, Y.S. Babu, J.A. Cox, S. Vijay-Kumar, J. Biol. Chem. 1991, 266,652 .

[9] Y. Luan-Rilliet, I. Gerber, T. Takagi, J.A. Cox, submitted to $J$. Biol. Chem.

[10] J.A. Cox, J. Biol. Chem. 1986, 261, 13173.

[11] J.A. Cox, Ph. Allard, O. Schaad, Prot. Engineering 1990, 4, 23.

[12] T. Takagi, J.A. Cox, J. Biol. Chem. 1990. 265,19721 .

[13] L. Valette-Talbi, C. Chaponnier, J.A. Cox, submitted to J. Histochem. Cytochem.

[14] R.H. Kretsinger, C.E. Nockolds, J. Biol. Chem. 1973, 248, 3313.

[15] N.C.J. Strynadka, M.N.G. James, Annu. Rev. Biochem. 1989, 58, 951.

Différentes équipes ont montré, par chromatographie sur couche mince, par chromatographie liquide haute performance et par spectrométrie de masse, qu'elles contiennent une quantité non négligeable

\title{
Détermination de la
} composition d'une préparation médicinale frauduleuse par des méthodes chromatographiques couplées (GC/MS, GC-FTIR, HPLC-DAD). Le cas des pilules chinoises Chuifong-Toukuwan

\author{
Philippe Arrizabalaga*, Aloïs Kamatari et Jean-Claude Landry
}

Abstract. The hyphenated techniques in chromatography (GC/MS, GC-FTIR, HPLC$\mathrm{DAD}$ ) are available for the molecular analysis of organic compounds. A traditional herbal medicine claimed to have a natural composition is studied by these appropriate methods. The analysis of crude and derivatized extracts of the pills showed that they are constitued by a mixture of synthetic drugs (mefenamic acid, indomethacine, hydrochlorothiazid, and diazepam) and some herbal compounds.

\section{Introduction}

L'attrait pour les médications naturelles associées à celui pour l'exotisme des pharmacopées orientales ont favorisé la vente clandestine de médicaments frauduleux [1].

Parmi eux, les pilules chinoises chuifong toukuwan présentent, aux dires du fabriquant, 'toutes les qualités requises pour soigner les maladies liées à l'effet du vent et de l'humidité tels que rhumatismes et arthrite'. Elles ne contiendraient que des extraits de plantes et ne présenteraient aucun risque pour la santé dans le cas de traitements prolongés. Les pilules sont des sphères noires, luisantes, d'environ $10 \mathrm{~mm}$ de diamètre, pesant en moyenne $440 \mathrm{mg}$. Elles sont constituées d'une enveloppe noire contenant une poudre blanchâtre hétérogène composée de particules plus ou moins colorées et cristallisées.

Elles sont vendues par correspondance et échappent à tout contrôle. Elles sont déjà responsables de nombreux accidents hématologiques (agranulocytose) aux Etats Unis [1] où elles circulent illicitement depuis quelques années. de molécules thérapeutiques de synthèse et que leur composition est variable [2-5].

Nous présentons, ici, les résultats obtenus par différentes techniques chromatographiques couplées de l'étude de ces pilules importées clandestinement en Suisse. Comme dans les travaux précédents, nous avons pu montrer la présence de produits de synthèse mais également et, pour la première fois, celle de composés naturels d'origine végétale dont l'activité thérapeutique avaitété décrite dans la pharmacopée traditionnelle orientale.

Les analyses ont été effectuées sur des extraits de produit brut dans le $\mathrm{MeOH}$ et des extraits méthylestérifiés. Les solutions ainsi obtenues ont été étudiées dans des conditions chromatographiques identiques.

L'identification des constituants a été réalisée par spectrométrie de masse et pour certains par spectroscopie infrarouge. Ces deux méthodes, séparément très fiables, permettent une caractérisation indiscutable des composés organiques.

\section{Partie expérimentales}

Chromatographie en phase gazeuse couplée à une spectrométrie de masse (GC/MS)

L'extrait brut est obtenu en traitant I pilule finement broyée par $15 \mathrm{ml}$ de $\mathrm{MeOH}(3 \times 5 \mathrm{ml})$ dans un bain à ultrasons pendant $30 \mathrm{~min}$. La soln. est ensuite filtrée (ISO-DISC N-254, diamètre 25 $\mu \mathrm{m}$, porosité $0,45 \mu \mathrm{m}$, Supelco) puis concentrée par évaporation sous vide. La dérivatisation se

*Correspondance: Dr. Ph. Arrizabalaga Service de l'écotoxicologie cantonal CP 78

CH-1211 Genève 8 